\title{
Pengembangan media pembelajaran berbasis android pada materi cahaya dan alat optik
}

\author{
F. N. Rahmawati, Munzil*, A. M. Setiawan \\ Universitas Negeri Malang, Jl. Semarang No. 5 Malang, Jawa Timur, Indonesia \\ *Penulis korespondensi, Surel: munzil.fmipa@um.ac.id
}

Paper received: 01-03-2021; revised: 15-03-2021; accepted: 31-03-2021

\begin{abstract}
Abstrak
Pembelajaran dengan menggunakan media dapat menunjang siswa dalam penguasaan konsep, menambah stimulus belajar khususnya rasa ingin tahu. Dari hasil observasi diperoleh bahwa Siswa kurang mengerti konsep pada materi cahaya serta alat optik dikarenakan siswa kurang tertarik dalam pembelajaran. Penelitian ini ditujukan agar dapat menghasilkan media pembelajaran mobile learning berbasis android pada materi cahaya serta alat optik yang diperuntukkan siswa SMP kelas VIII yang valid juga layak digunakan. Model penelitian yang dipakai dalam penelitian serta pengembangan ini adalah dari Alessi \& Trollip. Hasil validasi media mendapatkan 89,1 persen , validasi materi mendapatkan 100 persen, Hasil uji keterbacaan siswa mendapatkan 88,8 persen, oleh karena itu media dinyatakan sangat layak untuk digunakan sebagai media pembelajaran
\end{abstract}

Kata kunci: Android; Pemahaman Konsep; Cahaya dan Alat Optik

\section{Pendahuluan}

IPA membahas mengenai gejala alam yang tersusun secara sistematis berdasarkan hasil uji coba yang dilakukan manusia. Secara umum IPA tersusun dari 3 bidang ilmu dasar yakni fisika, kimia, biologi (Samatowa, 2006). Berdasarkan Peraturan Menteri Pendidikan Nasional Nomor 22 Tahun 2016, substansi IPA pada SMP/MTs yakni IPA tematik terpadu, maka pembelajaran IPA tematik terpadu mewajibkan guru IPA bertindak secara profesional, bisa menguasai materi IPA secara terpadu (dengan bidang kajian fisika, kimia, serta biologi) serta bisa mengembangkan materi dengan memakai perlengkapan yang layak dipakai (Febryana, dkk., 2015).

Selama ini pembelajaran IPA dinilai kurang relevan serta kurang populer dimata siswa (Yunita, 2017). Hal ini muncul dari respon siswa selama pembelajaran, suasana kelas terlihat ramai saat guru sedang menerangkan. Selain itu siswa juga banyak yang asik sendiri seperti bergurau dengan teman disampingnya. Siswa yang tidak mandiri dalam mengerjakan soal yang diberikan guru serta menunggu jawaban dari temannya, menjadi fakta dari rendahnya keinginan belajar juga pemahaman konsep IPA. Bukti dari rendahnya pemahaman konsep siswa terlihat dari hasil UN IPA SMP tahun 2012 yang hanya mencapai nilai rata-rata 6,5 (Iwantara, 2014). Hasil penelitian yang dilakukan kepada guru dari salah satu SMP di kota Malang mengatakan bahwa materi pelajaran IPA dengan kajian fisika di SMP yang tergolong susah untuk diajarkan kepada siswa yakni bab cahaya serta alat optik. Bab tersebut menempati materi nomor 2 paling sulit dipahami dari hasil riset yang dilakukan (Insani, 2016). Hal ini dikarenakan materi tersebut sangat abstrak serta dibutuhkan media pembelajaran yang benar agar siswa lebih mudah memahami materi bab cahaya sertaalat optik (Trianto, 2010).

Kondisi teknologi yang semakin berkembang, menjadikan landasan yang kuat untuk revolusi pembelajaran, salah satunya dengan Mobile Learning. M-Learning yaitu bentuk pembelajaran menggunakan perangkat teknologi komunikasi yang dapat bergerak tanpa 
terikat waktu serta tempat (Ghozi, 2014). Menurut Saefi,dkk. (2014), manfaat M-Learning yakni ketersediaan topik bahan ajar yang bisa diakses setiap saat beserta visualisasi materi yang unik serta menarik.

Dibutuhkan android seupaya bisa mengakses pembelajaran berbasis M-Learning. Android yakni sistem operasi linux yang dimodifikasi sehingga mempunyai kemampuan seperti sistem operasi sebuah komputer (Putra,dkk., 2016). Android mempunyai keunggulan serta kelemahan. Keunggulannya yakni bisa melakukan pendekatan yang komperhensif, free platform, serta sistem operasi merakyat. Kelemahannya yakni sistem operasi tersebut tidak hemat daya baterai (Ibrahim, 2017). Meskipun terdapat kekurangan dalam pembelajaran menggunakan media pembelajaran berbasis android, hal ini lebih baik dibandingkan dengan pembelajaran menggunakan metode ceramah saja atau konvensional.

Hasil penelitian yang dikerjakan oleh Ramadhani, dkk., (2016) adanya pengaruh dalam fungsi media mobile learning berbasis android dalam menghasilkan peningkatkan nilai siswa dari aspek pengetahuan. Hal ini menjadi bukti jika pembelajaran menggunakan media pembelajaran lebih baik dibandingkan pembelajaran dengan metode ceramah saja atau konvensional.

Berdasarkan perincian diatas, maka peneliti berkeinginan membuat penelitian pengembangan dengan judul "Pengembangan Media Pembelajaran Mobile Learning Berbasis Android pada Materi Cahaya serta Alat Optik untuk Siswa SMP Kelas VIII".

\section{Metode}

mewujudkan sebuah produk. Produk yang dirancang adalah media pembelajaran mobile learning berbasis android pada materi cahaya serta alat optik untuk siswa SMP tingkat VIII. Metode yang diperlukan dalam penelitian serta pengembangan media ini yakni metode pengembangan yang dikembangkan Alessi serta Trollip Alessi. Metode ini ditetapkan karena diorientasikan untuk pengembangan multimedia, model ini menjadi salah satu model yang diprioritaskan kepada pengembang pemula (Yogiyatno \& Sofyan, 2013).

Metode pengembangan Alessi \& Trollip dijelaskan pada Tabel 1.1.

\begin{tabular}{|c|c|}
\hline Tahap & Tujuan \\
\hline 1 & $\begin{array}{l}\text { Menyiapkan } \\
\text { pengembangan media } \\
\text { pembelajaran analisis } \\
\text { permasalahan } \\
\text { pembelajaran dan } \\
\text { mengumpulkan berkas } \\
\text { pengembangan }\end{array}$ \\
\hline 2 & $\begin{array}{l}\text { Menyiapkan } \\
\text { pengembangan media } \\
\text { pembelajaran melalui } \\
\text { pembuatan diagram } \\
\text { alur dan storyboard }\end{array}$ \\
\hline 3 & $\begin{array}{l}\text { Menyatukan komponen media agar dapat dilakukan } \\
\text { ujicoba yang tersusun dari uji Alpha serta uji Beta } \\
\text { 1. Uji Alpha dilakukan oleh ahli materi dan ahli media } \\
\text { 2. Uji Beta dilakukan oleh siswa SMP kelas VIII yang } \\
\text { sudah mengecap materi cahaya dan alat }\end{array}$ \\
\hline
\end{tabular}


Data yang diperoleh yakni data kuantitatif serta kualitatif. Data kuantitatif diterima dari angket yang diberikan ke validator serta subjek uji coba memakai skala Likert serta skala Guttman. Data kualitatif diterima oleh subjek uji coba terbatas berupa komentar beserta rekomendasi yang dijadikan sebagai bahan evaluasi demi membenahi produk. Media dianggap valid apabila memenuhi persentase $\geq 61 \%$

\section{Hasil dan Pembahasan}

Produk yang dikembangkan yakni media pembelajaran mobile learning berbasis android dengan materi cahaya serta alat optik. Sifat-sifat cahaya, pembentukan bayangan pada cermin serta lensa, indra penglihatan manusia serta serangga, juga alat optik yang lazim dijumpai sehari-hari. Materi yang diulas pada media pembelajaran ini sesuai dengan kompetensi dasar 3.12 mata pelajaran IPA kelas VIII kurikulum 2013. Produk ini diuraikan berdasarkan tujuan pembelajaran agar bisa dimanfaatkan sebagai media pembelajaran dikelas oleh guru serta mandiri oleh siswa

Adanya pengaruh baik oleh siswa ketika menggunakan media mobile learning berbasis android dalam menghasilkan peningkatan nilai siwa membuat produk ini layak untuk digunakan (ramadhani, dkk.,2016). Motivasi belajar pada peserta didik bisa dipengaruhi oleh kemenarikan media pembelajaran yang digunakan, sehingga dengan dorongan belajar yang tinggi akan meningkatkan rasa ingin tahu mereka serta mempermudah penerimaan materi pembelajaran (Fanny, 2013). Media pembe-lajaran berisi materi dapat dimanfaatkan oleh guru ketika proses pembelajaran dikelas serta media pembelajaran berisi latihan soal serta digunakan guru untuk mengetes kemampuan siswa saat memahami materi yang diajarkan guru.

Hasil uji kelayakan pada media pembe-lajaran dilaksanakan untuk melihat tingkat kelayakan juga kevalidan media yang sudah dikembangkan. Uji kelayakan dilakukan dengan dua langkah yakni uji Alpha serta uji Beta. Uji Alpha ialah validasi produk oleh ahli media serta ahli materi. Uji Beta yakni uji keterbacaan yang dilakukan oleh siswa kelas VIII SMP yang sudah menempuh materi cahaya serta alat optik. Hasil perhitungan pengembangan media yang telah dilakukan disajikan dalam Grafik 1.2

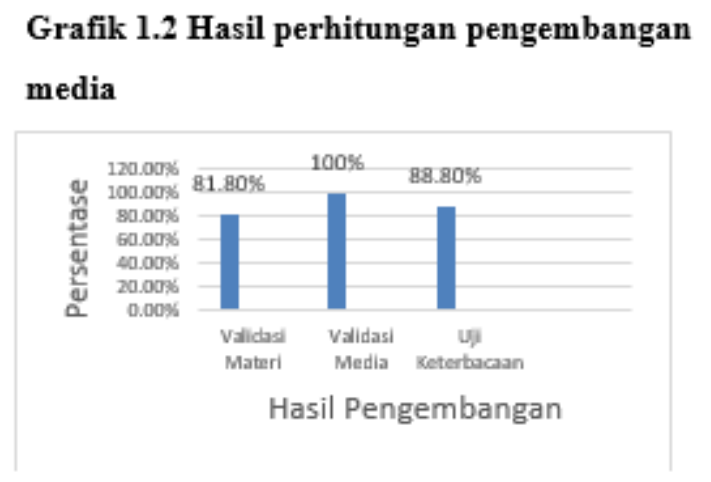

Dari hasil perhitungan yang telah dilakukan, media pembelajaran masuk dalam kategori sangat valid dari segi materi, media, serta uji keterbacaan, jadi dapat dikatakan jika media pembelajaran sangat layak untuk dimanfaatkan. 
Media pembelajaran ini bisa mendukung siswa untuk memahami konsep imajiner materi cahaya serta alat optik dengan visualisasi keadaan mikroskopis dari konsep yang dipelajari. Visualisasi dapat dilakukan dengan penyajian gambar, video animasi serta audio.

Penyajian materi pada media pembelajaran melalui gambar serta video animasi. Gambar tersebut bisa membantu siswa menginterpretasikan visualisasi melalui tampilan dua dimensi. Gambar sanggup menjelaskan definisi yang tidak sanggup dijelaskan dengan teks serta meringkas teks yang bersifat kompleks (Yudianto, A. 2017). Melalui gambar sanggup membantu siswa saat memahami teks lewat lambang visual sehingga mempermudah dalam pemahaman materi serta menumbuhkan minat belajar (Sadiman, A., 2006).

Video animasi merupakan sebuah ilustrasi dari kejadian yang tidak sanggup di indera secara langsung atau bersifat abstrak. Melalui animasi dapat membantu memvisualisasikan suatu keadaan tak kasat mata. Animasi pada media menyajikan pembentukan bayangain pada cermin, lensa, mata manusia, serta alat optik lainnya Dengan bantuan animasi dapat menampilkan gerakan serta bentuk mikroskopis yang tidak dapat diamati oleh indera sehingga dapat memberikan pengalaman baru kepada siswa sehingga dapat meningkatkan motivasi belajar siswa (Hasanah \& Lukman, 2015).

Latihan yang terdapat pada media pembelajaran ini sanggup dijadikan selama evaluasi untuk mengukur pemahaman konsep siswa melalui materi yang sudah dipelajari. Latihan menampilkan feedback langsung kepada siswa berupa skor pengerjaan yang ditampilkan ketika pengguna telah selesai mengerjakan semua soal. Feedback dari evaluasi berupa nilai serta terdapat keterangan berupa penghargaan yang dapat membuat siswa lebih termotivasi untuk belajar (Kuswanto \& Radiansah, 2017)

\section{Simpulan}

\subsection{Kesimpulan}

Hasil validasi media diperoleh persentase kevalidan sebesar $89,1 \%$ sehingga bisa dinyatakan sangat valid serta dapat diuji kelayakannya. Hasil validasi materi diperoleh persentase kevalidan sebesar $100 \%$ sehingga bisa dinyatakan sangat valid serta dapat diuji kelayakannya. Uji keterbacaan dilakukan oleh siswa SMP kelas VIII. Hasil uji keterbacaan oleh 15 siswa SMP jenjang VIII diperoleh persentase kelayakan sebesar $88,8 \%$ sehingga bisa dikatakan bahwa media sangat layak digunakan.

\subsection{Saran}

Dapat menindaklanjuti penelitian ini dengan ditambahkan waktu dalam pengerjaan latihan soal sehingga siswa dapat mempercepat pengerjaan latihan soal.

\section{Daftar Rujukan}

Alessi, S. M., \& Trollip, S. R. (2001). Multimedia for learning: Methods and development. Allyn \& Bacon.

Fanny, A. M., \& Suardiman, S. P. (2013). Pengembangan multimedia interaktif untuk mata pelajaran ilmu pengetahuan sosial (IPS) sekolah dasar kelas V. Jurnal Prima Edukasia, 1(1), 1-9.

Febryana, M., Sudarmi, M., \& Rondonuwu, F. S. (2015). Desain Pembelajaran IPA Terpadu pada Siswa SMP dengan Topik Pemanasan Global. Radiasi: Jurnal Berkala Pendidikan Fisika, 6(1), 30-37.

Ghozi, S. (2014). Pengembangan Materi Mobile Learning dalam Pembelajaran Matematika Kelas X SMA Perguruan Cikini Kertas Nusantara Berau. Indonesian Digital Journal of Mathematics and Education, 1(1), 22-30. 
Hasanah, U., \& Nulhakim, L. (2015). Pengembangan media pembelajaran film animasi sebagai media pembelajaran konsep fotosintesis. Jurnal Penelitian dan Pembelajaran IPA, 1(1), 91-106.

Insani, M. D. (2017). Studi pendahuluan identifikasi kesulitan dalam pembelajaran pada guru IPA SMP SeKota Malang. Jurnal Pendidikan Biologi, 7(2), 81-93.

Ibrahim, N., \& Ishartiwi, I. (2017). Pengembangan Media Pembelajaran Mobile Learning Berbasis Android Mata Pelajaran Ipa Untuk Siswa Smp. Refleksi Edukatika: Jurnal Ilmiah Kependidikan, 8(1).

Iwantara, I. W., Sadia, I. W., \& Suma, K. (2014). Pengaruh penggunaan media video youtube dalam pembelajaran IPA terhadap motivasi belajar dan pemahaman konsep siswa. Jurnal Pendidikan dan Pembelajaran IPA Indonesia, 4(1).

Kuswanto, J., \& Radiansah, F. (2018). Media Pembelajaran Berbasis Android Pada Mata Pelajaran Sistem Operasi Jaringan Kelas XI. Jurnal Media Infotama, 14(1).

Putra, D. W., Nugroho, A. P., \& Puspitarini, E. W. (2016). Game Edukasi berbasis android sebagai media pembelajaran untuk anak usia dini. JIMP-Jurnal Informatika Merdeka Pasuruan, 1(1).

Ramadhani, D. G., Mulyani, B., \& Utomo, S. B. (2016). Pengaruh Penggunaan Media Mobile Learning Berbasis Android Dan LKS Dalam Model Pembelajaran Student Team Achivement Division (STAD) Terhadap Prestasi Belajar Ditinjau Dari Kemampuan Memori Pada Materi Pokok Sistem Koloid Kelas XI SMA Negeri 2 Purwokerto. Jurnal Pendidikan Kimia, 5(4), 16-25.

Saefi, M. (2015). Pengembangan media mobile learning berbasis android pada pembelajaran Struktur dan Fungsi Sel kelas XI (Doctoral dissertation, Universitas Negeri Malang).

Samatowa, U. (2006). Bagaimana membelajarkan IPA di sekolah dasar. PT Pustaka Indonesia Press.

Trianto, T. (2010). Model pembelajaran terpadu. Jakarta: Bumi Aksara.

Wahyuni, D. R. (2015). PENINGKATAN PRESTASI BELAJAR SISWA DALAM PEMBELAJARAN IPA MATERI BUNYI DENGAN MENERAPKAN METODE KOOPERATIF MODEL JIGSAW DI KELAS VIII A SMP NEGERI 2. Florea: Jurnal Biologi dan Pembelajarannya, 2(1).

Yektyastuti, R., \& Ikhsan, J. (2016). Pengembangan media pembelajaran berbasis android pada materi kelarutan untuk meningkatkan performa akademik siswa SMA. Jurnal Inovasi Pendidikan IPA, 2(1), 88-99.

Yogiyatno, W., \& Sofyan, H. (2014). Pengembangan multimedia interaktif kompetensi dasar mengoperasikan software basis data untuk SMK Negeri 1 Seyegan. Jurnal Pendidikan Vokasi, 4(1).

Yunita, D., \& Wijayanti, A. (2017). Pengaruh Media Video Pembelajaran Terhadap Hasil Belajar IPA Ditinjau Dari Keaktifan Siswa. Sosiohumaniora: Jurnal Ilmiah Ilmu Sosial Dan Humaniora, 3(2).

Yudianto, A. (2017). Penerapan Video Sebagai Media Pembelajaran. 